\title{
Records of climatic changes and volcanic events in an ice core from Central Dronning Maud Land (East Antarctica) during the past century
}

\author{
V N Nijampurkar ${ }^{1}$, D K RaO ${ }^{1}$, H B Clausen ${ }^{2}$, M K Kaul $^{3}$ and A Chaturvedi ${ }^{3}$ \\ ${ }^{1}$ Physical Research Laboratory, Ahmedabad, India \\ ${ }^{2}$ Department of Geophysics, Niels Bohr Institute of Astronomy, \\ Physics and Geophysics, DK 2200 Copenhagen O, Denmark \\ ${ }^{3}$ Geological Survey of India, Antarctica Division, Faridabad, India
}

\begin{abstract}
The depth profiles of electrical conductance, $\delta^{18} \mathrm{O},{ }^{210} \mathrm{~Pb}$ and cosmogenic radio isotopes ${ }^{10} \mathrm{Be}$ and ${ }^{36} \mathrm{Cl}$ have been measured in a $30 \mathrm{~m}$ ice core from east Antarctica near the Indian station, Dakshin Gangotri. Using ${ }^{210} \mathrm{~Pb}$ and $\delta^{18} \mathrm{O}$, the mean annual accumulation rates have been calculated to be 20 and $21 \mathrm{~cm}$ of ice equivalent per year during the past $\sim 150$ years. Using these acumulation rates, the volcanic event that occurred in $1815 \mathrm{AD}$, has been identified based on electrical conductance measurements. Based on $\delta^{18} \mathrm{O}$ measurements, the mean annual surface air temperatures (MASAT) data observed during the last 150 years indicates that the beginning of the 19th century was cooler by about $2^{\circ} \mathrm{C}$ than the recent past and the middle of 18 th century. The fallout of cosmogenic radio isotope ${ }^{10} \mathrm{Be}$ compares reasonably well with those obtained on other stations $\left(73^{\circ} \mathrm{S}\right.$ to $\left.90^{\circ} \mathrm{S}\right)$ from Antarctica and higher latitudes beyond $77^{\circ} \mathrm{N}$. The fallout of ${ }^{36} \mathrm{Cl}$ calculated based on the present work agrees well with the mean global production rate estimated earlier by Lal and Peters (1967). The bomb pulse of ${ }^{36} \mathrm{Cl}$ observed in Greenland is not observed in the present studies - a result which is puzzling and needs to be studied on neighbouring ice cores from the same region.
\end{abstract}

\section{Introduction}

Long ice cores from polar ice sheets provide information on continuous records of past volcanic eruptions and accumulation rates of ice, climatic and environmental changes, atmospheric and nuclear fallout, and solar and terrestrial variability for several thousands of years (Orheim et al 1986; Delmas et al 1992; Nijampurkar and Rao 1993a; Beer et al 1994; Stuiver et al 1995 and Hammer et al 1997). In recent years, there has been considerable interest to study short term (a few centuries), high resolution records of climate and environment from archives such as glaciers, ice sheets, tree rings and lake sediments (Orheim et al 1986; Ramesh et al 1989; Nijampurkar and Rao 1993a and Petterson et al 1993) These records often show interannual varia- tions in global surface air temperature, sea surface temperature and precipitation which appear to correlate with 11 year solar cycle, heavy rainfall and flood events (Seleshi et al 1994 and Currie 1994).

Measurements of the DC electrical conductivity of solid ice (EC) is a quick and powerful tool for obtaining historical records of volcanic eruptions in terms of deposition of strong acids $\mathrm{H}_{2} \mathrm{SO}_{4}$, $\mathrm{HCl}$ and micro particles. These records also provide precise accumulation rates of ice, giving accurate time index during the past several thousands of years (Hammer et al 1997). Stable isotopes of oxygen $\left(\delta^{18} \mathrm{O}\right)$ are excellent time markers and climatic indicators (Jouzel et al 1987). Natural radio isotopes of different half-lives $\left({ }^{210} \mathrm{~Pb},{ }^{10} \mathrm{Be}\right.$ and $\left.{ }^{36} \mathrm{Cl}\right)$ give information about their fallout and depositional history during different time scales. Whereas

Keywords. Antarctica; Electrical Conductivity Measurements (ECM); accumulation rates; climate; ${ }^{10} \mathrm{Be}$ and ${ }^{36} \mathrm{Cl}$. 


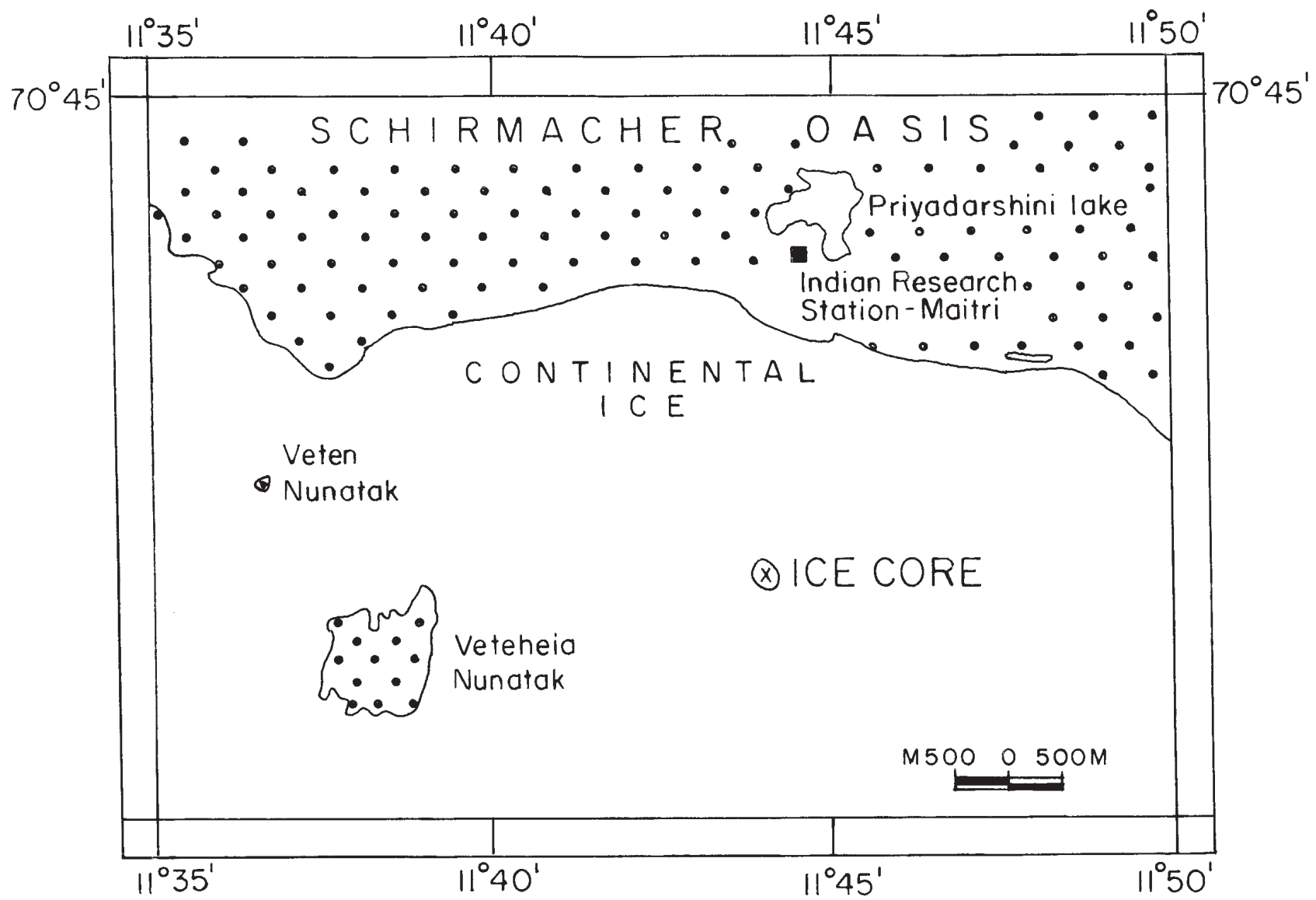

Figure 1. Location map of the site from where $60 \mathrm{~m}$ ice core was raised during the Indian expedition to Antarctica in 1992.

${ }^{210} \mathrm{~Pb}\left(t_{1 / 2}=22.3 \mathrm{a}\right)$ gives accumulation rates of ice during the last century (Gaggeler et al 1983), the cosmogenic radio isotope ${ }^{10} \mathrm{Be}\left(t_{1 / 2}=16 \mathrm{Ma}\right)$ with a much longer half-life gives long term accumulation rates of ice during millions of years and information on climatic changes, solar cycles and sun spot activities during different time scales (Beer et al 1991). Another cosmogenic isotope ${ }^{36} \mathrm{Cl}\left(t_{1 / 2}=0.3 \mathrm{Ma}\right)$ also produced during testing of nuclear weapons from 1950-1980, is a useful tracer to study transport process in the atmosphere and hydrology (Synal et al 1990). These two cosmogenic isotopes are promising proxies to reconstruct solar and terrestrial variability on the scales longer than a few centuries (Beer, personal communication, 1998). The ${ }^{10} \mathrm{Be} /{ }^{36} \mathrm{Cl}$ ratio is very useful for dating older ice (Nishiizumi et al 1983). Since the data, until this date, for these isotopes is sparse on the southern hemisphere (Antarctica) in comparison to that from Greenland and other Polar regions from northern hemisphere, we present in this paper the results of the part of the ice core (3$10 \mathrm{~m}$ ) for ${ }^{10} \mathrm{Be}$ and ${ }^{36} \mathrm{Cl}$ concentrations during the last 35 years. Recently Aldahan et al (1998) have published data for ${ }^{10} \mathrm{Be}$ in a core from Antarctica in a nearby site spanning a period of 60 years B.P. The main objective of this study is to compare the levels of concentrations of ${ }^{10} \mathrm{Be}$ and ${ }^{36} \mathrm{Cl}$ during the past few decades with available data (Aldahan et al 1998) from other locations and to compare our data with the bomb pulse of ${ }^{36} \mathrm{Cl}$ observed in Greenland from 1940-1980.

In view of the above, we discuss the data of our analysis of the first $60 \mathrm{~m}$ ice core raised from east Antarctica near the Indian station, Dakshin Gangotri, in 1992 in terms of short term climatic changes $\left(\delta^{18} \mathrm{O}\right)$, volcanic eruptions (ECM), accumulation rates of ice $\left({ }^{210} \mathrm{~Pb}, \delta^{18} \mathrm{O}, \mathrm{ECM}\right)$ and fallout of cosmogenic ${ }^{10} \mathrm{Be}$ and ${ }^{36} \mathrm{Cl}$ during the last 150 years. Due to technical constraints, measurements were carried out only on part of the $30 \mathrm{~m}$ top core $(\sim 150$ years $)$.

\section{Location and sample collection}

The $60.46 \mathrm{~m}$ ice core was raised in the continental ice by the Geological Survey of India (G.S.I) south of the Indian Research Station, Maitri, in Central Dronning Maud Land, East Antarctica during the austral winter of the 12th Indian scientific expedition to Antarctica in 1992 (Chaturvedi et al 1996). The drilling site was $\sim 3 \mathrm{~km}$ east of the Nunatak Vateheia at location $70^{\circ} 47^{\prime} \mathrm{S}, 11^{\circ} 44^{\prime} \mathrm{E}$ south of Schirmachar Oasis (figure 1). 
Table 1. Various parameters, techniques used in the present study and their applications.

\begin{tabular}{|c|c|c|c|}
\hline S.No & Parameter & Technique & Importance \\
\hline 1. & $\delta^{18} \mathrm{O}$ & Mass spectrometry & $\begin{array}{l}\text { Climatic changes } \\
\text { Accumulation rates }\end{array}$ \\
\hline 2. & ${ }^{10} \mathrm{Be},{ }^{36} \mathrm{Cl}$ & $\begin{array}{l}\text { Accelerator mass } \\
\text { spectrometry }\end{array}$ & $\begin{array}{l}\text { Solar and terrestrial variability } \\
\text { Atmospheric transport } \\
\text { Climatic variations } \\
\text { Dating of polar ice }\end{array}$ \\
\hline 3. & $\begin{array}{l}{ }^{210} \mathrm{~Pb} \\
\text { Total } \beta\end{array}$ & $\begin{array}{l}\text { Radiation detectors } \\
(\alpha, \beta)\end{array}$ & Accumulation rates \\
\hline 4. & Solid conductance & Indigeneous conductometer & $\begin{array}{l}\text { Past volcanic records } \\
\text { Accumulation rates }\end{array}$ \\
\hline 5. & Density & Conventional technique & Study of densification \\
\hline
\end{tabular}

The lowest minimum air temperature recorded during the period was $-34.5^{\circ} \mathrm{C}$ in the month of August 1993. Scanty snow fall and wind-borne snow was witnessed intermittently all round the year, particularly during winter and the spring months and was generally associated with blizzards. Out of the total $60.46 \mathrm{~m}$ of the ice core, more than $95 \%$ was recovered in unshattered columns. The average length of each column was about $60 \mathrm{~cm}$; though, at times, individual core of $2 \mathrm{~m}$ length have also been obtained. The physical logging of the core was done in the field.

The entire core was cut into 302 sections of about $20 \mathrm{~cm}$ each at the sampling site and kept frozen in ultra clean wide mouth plastic bottles. These samples for all sections were photographed and later subjected to density stratigraphic studies in the field. However, these measurements could not be carried out on the first thirteen samples from the top $2.9 \mathrm{~m}$ because they were collected as broken ice bits.

The complete core was transported from Antarctica to Goa by ship in a frozen condition and preserved at $-20^{\circ} \mathrm{C}$ in a cold storage and later transported in a refrigerated vehicle to Ahmedabad and stored in a refrigerator till the time of analysis.

\section{Analytical procedures}

After obtaining the photographic records of the various sections of the core and density stratigraphy in the field, the core sections were subjected to analysis for the different parameters (EC, $\left.\delta^{18} \mathrm{O},{ }^{210} \mathrm{~Pb},{ }^{10} \mathrm{Be},{ }^{36} \mathrm{Cl}\right)$ in different laboratories (see sections 3.1 and 3.2). Table 1 gives the various parameters, techniques used in the present study and their applications.

\subsection{Electrical conductivity (EC) measurements}

About $20 \mathrm{~cm}$ cylindrical sections of the core from $3-30 \mathrm{~m}$ depth was cleaned by scraping off a few $\mathrm{mm}$ of the surface ice using an ultra clean stainless steel knife. The electrical conductivity of the cleaned solid ice core section was measured at $-18^{\circ} \mathrm{C}$ in a vertical model deep freezer using the Electrical Conductivity Method. The acidity of the core was monitored in terms of the current using an EC system developed at PRL on similar lines following those available (Hammer 1980).

\section{$3.2 \delta^{18} \mathrm{O},{ }^{210} \mathrm{~Pb},{ }^{10} \mathrm{Be}$ and ${ }^{36} \mathrm{Cl}$ measurements}

After EC measurements, each section of $20 \mathrm{~cm}$ core was subsampled in $2-3 \mathrm{~cm}$ interval for $\delta^{18} \mathrm{O}$ measurements and preserved frozen until analysis. The remaining part of each $20 \mathrm{~cm}$ section $(\sim 2 \mathrm{~L})$ was preserved in a frozen condition before analysis for ${ }^{210} \mathrm{~Pb},{ }^{10} \mathrm{Be}$ and ${ }^{36} \mathrm{Cl}$.

The $\delta^{18} \mathrm{O}$ measurements were made at the Department of Geophysics, Copenhagen, Denmark by two authors using an auto mass spectrometer as per standard procedures (Dansgaard 1964). We obtained a continuous low resolution record of $\delta^{18} \mathrm{O}$ measurements from $0-3$ meters representing ice melt waters (not in frozen condition) each of $20 \mathrm{~cm}$ ice fractions. However these samples were probably subjected to evaporation, melting and refreezing disturbing their original $\delta^{18} \mathrm{O}$ signatures during sampling, transporting and storage before measurements. These results, therefore, are not included in the text for the discussion of comparison of their $\delta^{18} \mathrm{O}$ concentrations and interpretation of accumulation of ice and climatic variations.

${ }^{210} \mathrm{~Pb}$ activities in the melt water samples $(\sim 1 \mathrm{~L})$ were measured as per the standard procedures using $\alpha$ spectrometry (Sarin et al 1992). In brief, these samples were acidified with $6 \mathrm{~N} \mathrm{HCl}$ so as to maintain the $\mathrm{pH} \sim 1-2$ and were spiked with known activity of ${ }^{209} \mathrm{Po}$. After equilibration of spike, samples were evaporated to dryness and the residue was dissolved in $50 \mathrm{ml}$ of $0.6 \mathrm{~N} \mathrm{HCl}$. From this solution, polonium isotopes were plated on silver planchet and their activities were assayed 
by alpha spectrometry using silicon surface barrier detectors. From the measured activity of ${ }^{210} \mathrm{Po}$, the in situ ${ }^{210} \mathrm{~Pb}$ activity in the samples were calculated.

${ }^{10} \mathrm{Be}$ and ${ }^{36} \mathrm{Cl}$ activity measurements were made at the AMS facility of ETH/AST in Zurich, Switzerland. Be and $\mathrm{Cl}$ spikes (supplied by J Beer) were added to bi-annual samples during melting of the ice. The samples in the ultra clean, leak proof plastic bottles were sent to the AMS laboratory of Prof. J Beer for ${ }^{10} \mathrm{Be}$ and ${ }^{36} \mathrm{Cl}$ analysis. The samples cover approximately the time period of nuclear testing from 1980-1940 AD, and they were analysed as per the standard procedures published earlier (Beer et al 1994).

\section{Results and discussion}

\subsection{Physical examination of the core}

Photographic and density stratigraphy studies were conducted in the field by G.S.I. (Geological Survey of India) scientists. The photographic record of the core did not reveal any specific information regarding trapped dust particles. No dust horizon was observed in any section of the core. The density of the solid sections of the core varied from 890 to $910 \mathrm{~kg} / \mathrm{m}^{3}$ (Chaturvedi et al 1996) from 3 to $60 \mathrm{~m}$ depth with a variation of $\sim 2 \%$ up to $60 \mathrm{~m}$ depth. However the density of the top sections of the core from $0-3 \mathrm{~m}$ could not be measured as these samples were recovered in broken bits.

\subsection{Electrical Conductivity (EC) measurements}

The EC profile shown in figure 2 indicates that the high background of the instrument $(2 \pm 2 \mu \mathrm{amp})$ is probably due to non-ideal laboratory conditions (like non availability of cold room facility generally maintained at $-18^{\circ}$ to $-20^{\circ} \mathrm{C}$ for such measurements) during the course of EC measurements of all the samples. The sharp peaks of magnitude $>10 \mu \mathrm{amp}$ (saturated values of currents due to limitations of the instrument) at few depths (time) could be related to historical volcanic eruptions during the past 150 years and can be subsequently used for dating older ice. A sharp peak of $>10 \mu \mathrm{amp}$ occurring at a depth of about $30 \mathrm{~m}$ could be related to the major eruption 'TAMBORA' that occurred in Indonesia $\left(10^{\circ} \mathrm{S}\right)$ in $1815 \mathrm{AD}$. The other sharp peak observed at $5 \mathrm{~m}$ depth around 1963-64 which can be attributed to volcanic eruption that occurred at $1^{\circ} \mathrm{S}$ (AUGUNG) in 1963. Four unidentified peaks of similar magnitudes were observed at depths between 3 and $4 \mathrm{~m}$ probably due to major eruptions that might have occurred recently (i.e., after
1963) in the southern hemisphere. They, however, could not be related to any specific known volcanic events.

The volcanic eruption of 'TAMBORA' that erupted in 1815AD has been used to calculate an accumulation rate of $\sim 17 \pm 0.08 \mathrm{~cm} / \mathrm{yr}$ which agrees reasonably well with those obtained by ${ }^{210} \mathrm{~Pb}$ and $\delta^{18} \mathrm{O}$ (see discussion 4.3 and 4.4).

Due to some constraints in the logistic facilities in storage and transportation of the ice cores, the data are interpreted with caution.

\section{$4.3{ }^{210} \mathrm{~Pb}$ activities}

The ${ }^{210} \mathrm{~Pb}$ activities up to a depth of $20 \mathrm{~m}$ have been measured (by combining 8 sections of the core each of $160 \mathrm{~cm}$ to obtain easily measurable signals of ${ }^{210} \mathrm{~Pb}$ activities). The results of 7 samples is plotted on figure 3, The best fit line of the data gives an average accumulation rate of $20 \pm 2 \mathrm{~cm} / \mathrm{yr}$ during the past 100 years. It appears from figure 3 that the accumulation rate of ice has not remained constant during the last century and varies from 12.5 to $26.6 \mathrm{~cm} / \mathrm{yr}$ with a mean value of $20 \pm 2 \mathrm{~cm} / \mathrm{yr}$. Figure 3 shows that the ${ }^{210} \mathrm{~Pb}$ activity at a depth of $\sim 10 \mathrm{~m}$ is decreased by a factor of $\sim 4$ (about 2 half-lives of ${ }^{210} \mathrm{~Pb}$ ) relative to that at $3 \mathrm{~m}$. This indicates that the depth interval from $3-10 \mathrm{~m}$ covers a time span of $\sim 50$ years (1990-1940) - a period of nuclear tests. This also suggests an age of 150 years at the depth $30 \mathrm{~m}$. The fallout of ${ }^{210} \mathrm{~Pb}$ calculated from the present work $\left(2.6 \times 10^{-2} \mathrm{dpm} / \mathrm{cm}^{2} \mathrm{yr}\right)$ agrees well with the mean fallout of $3 \times 10^{-2} \mathrm{dpm} / \mathrm{cm}^{2}$ yr for different locations in $60^{\circ}-90^{\circ}$ belt in southern hemisphere (Crozaz et al 1964; Picciotto et al 1964; Nijampurkar and Rao 1993b). However, the mean value of ${ }^{210} \mathrm{~Pb}$ fallout estimated in the $60^{\circ}-90^{\circ}$ belt in the northern hemisphere is higher by a factor of $\sim 2\left(5 \times 10^{-2} \mathrm{dpm} / \mathrm{cm}^{2} \mathrm{yr}\right.$, Crozaz and Langway $1966)$.

\section{$4.4 \delta^{18} \mathrm{O}$ measurements}

$\delta^{18} \mathrm{O}$ records in the polar ice cores have often been used to determine the accumulation rates of ice and the mean annual surface air temperatures (MASAT) at the site of precipitation (Dansgaard 1964). $\delta^{18} \mathrm{O}$ measurements carried out in the present work are discussed in the light of these parameters.

The depth profile of the continuous record of $\delta^{18} \mathrm{O}$ measurements for $3-6 \mathrm{~m}$ depth of the core is given in figure 4 . The continuous high resolution $\delta^{18} \mathrm{O}$ record shows clear cyclic variations and annual cycles with summer and winter peaks. These data have been used for calculation of 


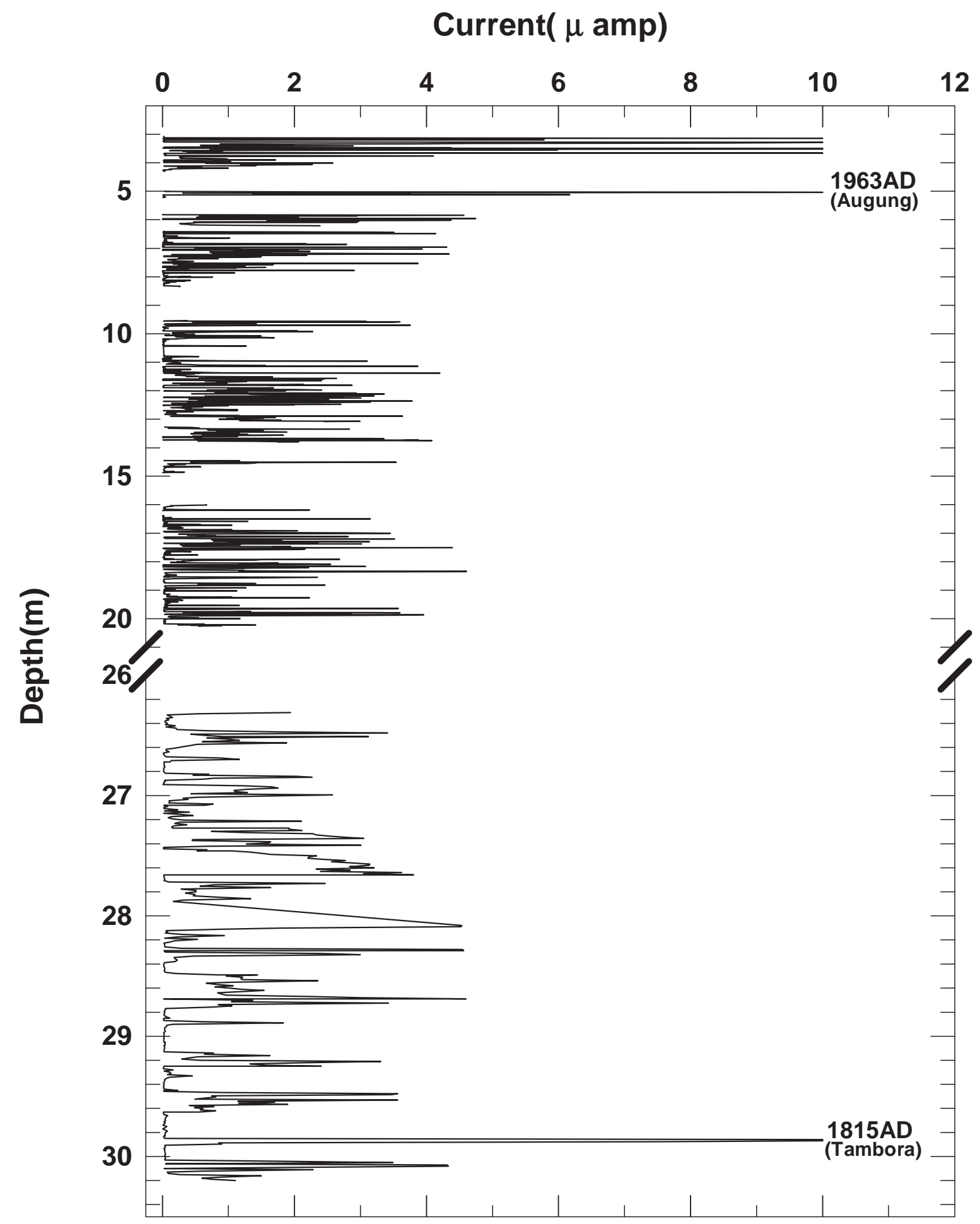

Figure 2. Electrical conductivity measurements of the solid ice core samples from 0-30 m depth at an interval of $20 \mathrm{~cm}$. The peak saturated values of currents $(\mu \mathrm{amp})$ at about 5 and $30 \mathrm{~m}$ depths identify the past volcanic episodes Augung (1963AD) and Tambora (1815 AD) respectively. For unidentified peaks between 3 and $4 \mathrm{~m}$ depth, please refer section 4.2

(i) accumulation rates of ice and (ii) MASAT at the site of precipitation using empirical linear relationship established between mean annual $\delta^{18} \mathrm{O}$ and MASAT (Dansgaard 1964). In the absence of any other good time marker (e.g., $\left.{ }^{137} \mathrm{Cs}\right){ }^{210} \mathrm{~Pb}$ has been used to calculate and compare the ages of ice samples and used as time index to study the deposi- tional history of the ice core and climatic variations at the site of precipitation.

The $\delta^{18} \mathrm{O}$ values for the depth $3-6 \mathrm{~m}$ (figure 4) equivalent to 1977-1962 $\mathrm{AD}$, vary from -21.4 to $-26.5 \%$. The accumulation rate of ice during this period is not uniform and varies from 8 to $46 \mathrm{~cm} / \mathrm{yr}$ and the mean has been calcu- 


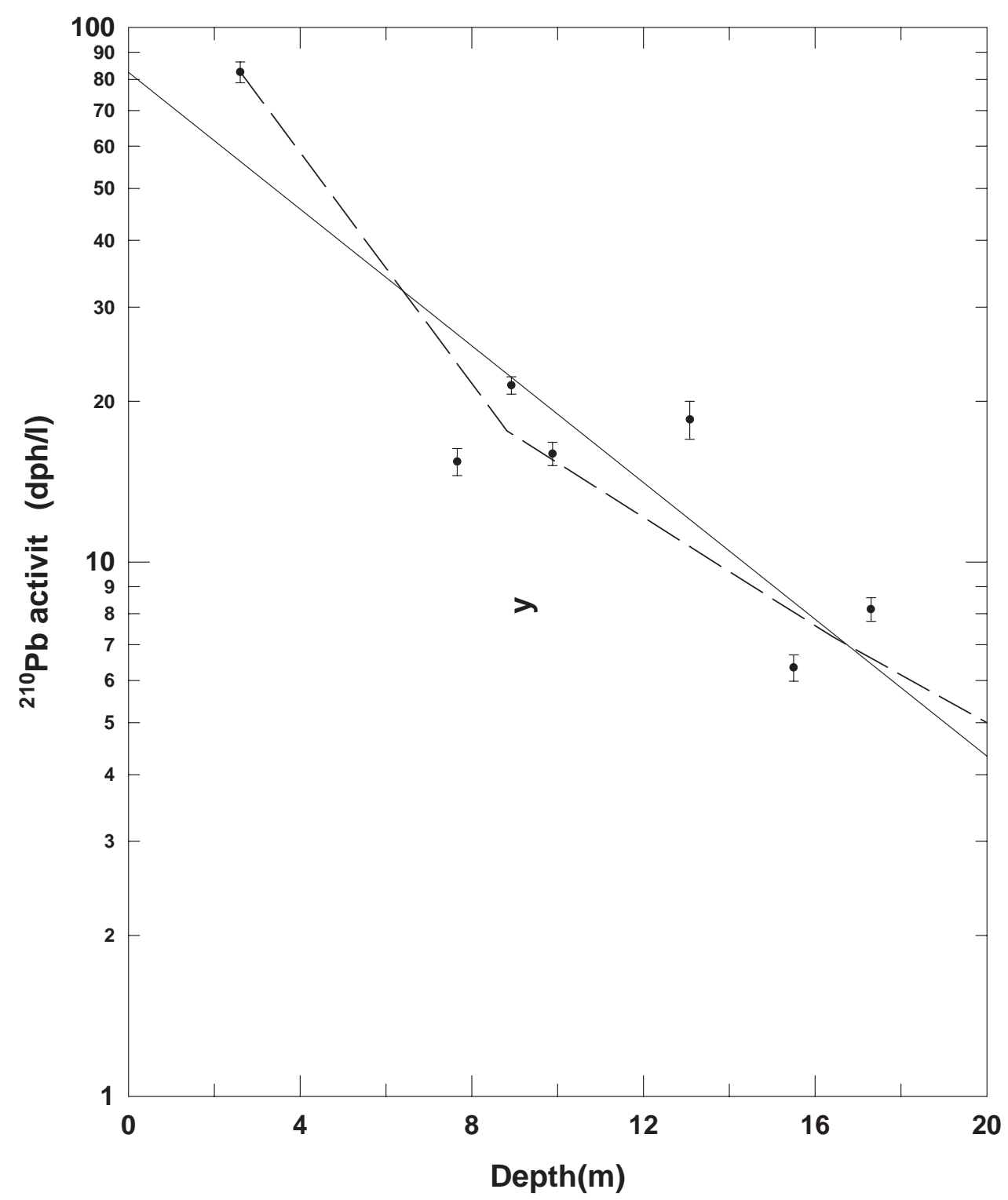

Figure 3. Depth profile of ${ }^{210} \mathrm{~Pb}$ specific activities in the ice core up to $18 \mathrm{~m}$ depth. The past average accumulation rate of ice has been calculated to be $20 \pm 2 \mathrm{~cm} / \mathrm{yr}$ using the best-fit line of these data. The depth profile, however, shows that the accumulation rate has varied during the past century.

lated to be $21 \pm 0.10 \mathrm{~cm} / \mathrm{yr}$. The accumulation rate of ice during the first two years (corresponding to 3-4 $\mathrm{m}$ depth) are observed to be higher by a factor of two compared to the calculated mean value. Similarly the discontinuous cyclic record of $\delta^{18} \mathrm{O}$ concentrations shows that the accumulation rate of ice varies from 16 to $26 \mathrm{~cm} / \mathrm{yr}$ during the time period equivalent to $6-30 \mathrm{~m}$ (1960-1840AD). The average MASAT value for the period equivalent to $3-6 \mathrm{~m}$ has been calculated to be $-15^{\circ} \mathrm{C}$ (table 2). Figure 5 shows the average MASAT values verses depth of 3 $30 \mathrm{~m}$. The individual MASAT values for the different periods have been calculated which vary from -15 to $-17.6^{\circ} \mathrm{C}$ and shows lowest MASAT of $-17.6 \pm 0.2^{\circ} \mathrm{C}$ at $\sim 1900 \mathrm{AD}$. More measurements are needed to confirm the trend and minima at $\sim 1900$ AD. Table 2 shows the mean annual $\delta^{18} \mathrm{O}$, average MASAT, age (yr) and time (AD) for the different periods corresponding to different depths from $3-30 \mathrm{~m}$. It is clear from table 2 and figure 5 that the MASAT for the period equivalent to 17.8 to $18.0 \mathrm{~m}$ depth (i.e., beginnning of the 19th century) was lower by $\sim 2^{\circ} \mathrm{C}$ compared to other time periods.

The data therefore indicate that the average accumulation rate at this site during the last 150 years is about $20 \mathrm{~cm} / \mathrm{yr}$ and that a few decades at the beginning of the century (1920-1890 AD) were cooler by $\sim 2^{\circ} \mathrm{C}$ than the other periods during the recent past (1977-1920 AD) and middle of 18th century (1890-1840 AD). The accumulation, however, is not uniform during this period and shows large interannual and decadal variations. 


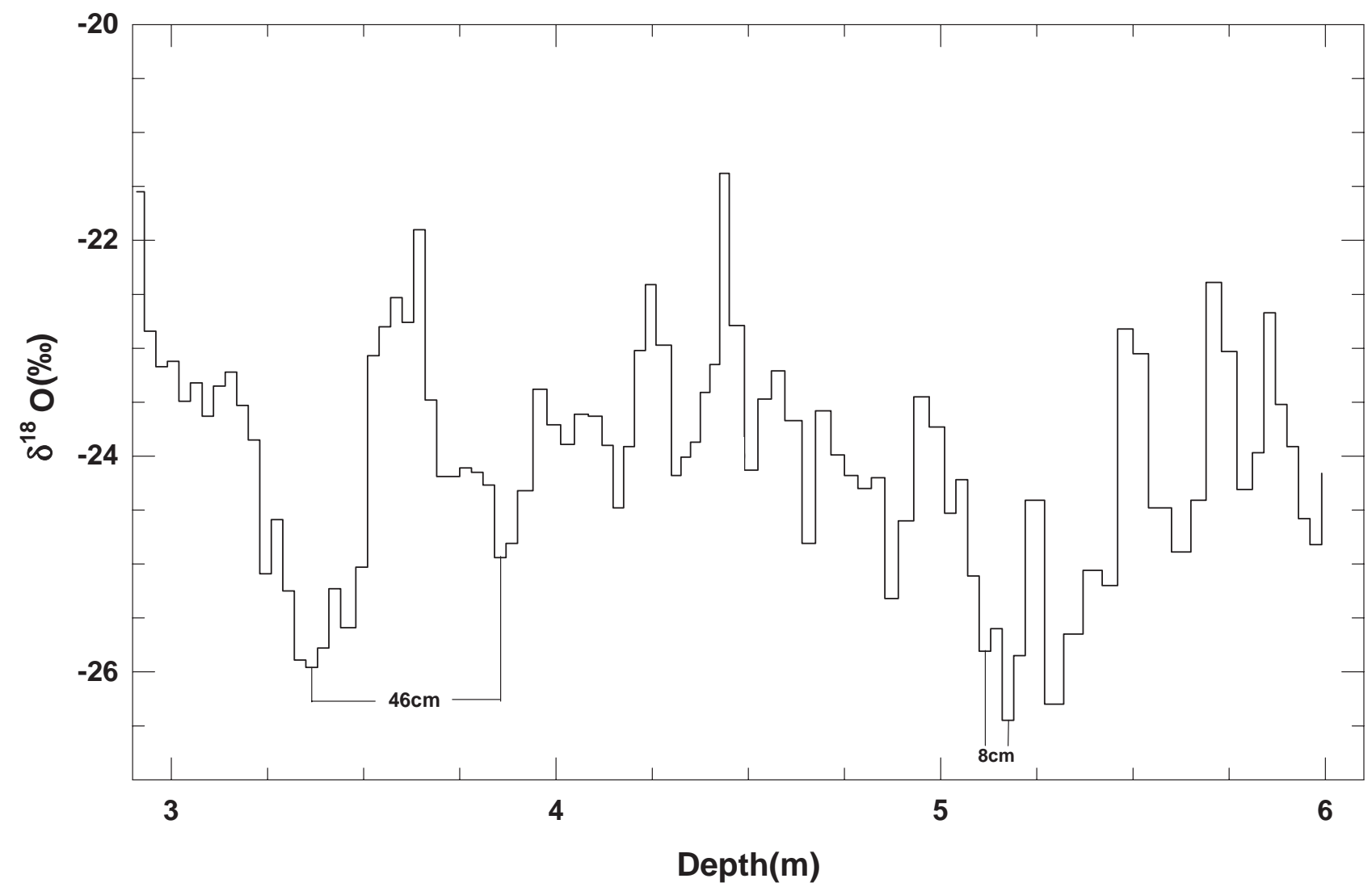

Figure 4. Variation in $\delta^{18} \mathrm{O}$ between 3 and $6 \mathrm{~m}$ depth is drawn on expanded scale. Using their cyclic variations, an accumulation rate for ice has been estimated which varies from 8 to $46 \mathrm{~cm}$ with an average value of $20 \mathrm{~cm} / \mathrm{yr}$.

Table 2. Mean annual $\delta^{18} \mathrm{O}\left(\%\right.$ ) , average MASAT $\left({ }^{\circ} \mathrm{C}\right)$ values at different periods derived from $60 \mathrm{~m}$ ice core raised at Dakshin Gangotri from east Antarctica.

\begin{tabular}{|c|c|c|c|c|c|}
\hline Sl.No. & $\begin{array}{l}\text { Depth } \\
(\mathrm{m})\end{array}$ & $\begin{array}{c}\text { Mean annual } \\
\delta^{18} \mathrm{O}(\% \%)\end{array}$ & $\begin{array}{c}\text { Mean MASAT } \\
\text { temp }\left({ }^{\circ} \mathrm{C}\right)\end{array}$ & $\begin{array}{l}\text { Age } \\
(\mathrm{yr})\end{array}$ & $\begin{array}{l}\text { Time } \\
\text { (AD) }\end{array}$ \\
\hline 1 & $3.1-5.8$ & -24 & -15 & 22 & 1970 \\
\hline 2 & $9.8-10.0$ & -24.6 & -15.8 & 49.5 & 1942 \\
\hline 3 & $13.1-13.2$ & -24.5 & -15.7 & 65.8 & 1926 \\
\hline 4 & $17.8-18.0$ & -25.8 & -17.6 & 89.6 & 1902 \\
\hline 5 & $27.7-27.9$ & -24.6 & -15.8 & 139 & 1853 \\
\hline
\end{tabular}

$\delta^{18} \mathrm{O}$ values from DMI $\left(74^{\circ} \mathrm{S} 12^{\circ} \mathrm{W}\right)$, east Antarctica closer to our station vary from -14 to $-26 \%$ during the last 50 years (Aldahan et al 1998) but the accumulation rate is higher by a factor of two than that estimated from the present work.

\section{$4.5{ }^{10} \mathrm{Be}$ and ${ }^{36} \mathrm{Cl}$ studies}

The importance of polar fallout of cosmogentic isotopes ${ }^{10} \mathrm{Be}$ and ${ }^{36} \mathrm{Cl}$ (also produced artificially during nuclear detonations) has been discussed briefly in the introduction (see section 1). ${ }^{10} \mathrm{Be}$ and ${ }^{36} \mathrm{Cl}$ measurements have been made for the ice samples which represent a time period of 1940-1975AD. The ${ }^{10} \mathrm{Be}$ values (table 3) range from 0.56 to $2.58 \times 10^{4}$ atoms $/ g$ with a mean value of $1.16 \times 10^{4}$ atoms $/ g$ which agrees well with those calculated at Renland ice core from Greenland and DML ice core from Antarctica (Aldahan et al 1998). Among the ${ }^{10} \mathrm{Be}$ concentrations, only one sample had ${ }^{10} \mathrm{Be}$ in excess of $1.5 \times$ $10^{4}$ atoms $/ \mathrm{g}$, at $500 \mathrm{~cm}$ depth with a value of $2.58 \times$ $10^{4}$ atoms/g.

The deposition of ${ }^{10} \mathrm{Be}\left(2 \times 10^{5}\right.$ atoms $/ \mathrm{cm}^{2}$ yr $)$ determined in the present work agrees reasonably well with those derived for other regions at higher latitudes in Antarctica $\left(73^{\circ} \mathrm{S}\right.$ to $\left.90^{\circ} \mathrm{S}\right)$. The ${ }^{10} \mathrm{Be}$ fallout at locations in northern hemisphere, however, are higher by factors of $2-3$. The ${ }^{10} \mathrm{Be}$ deposition values have smaller variance and lower annual 


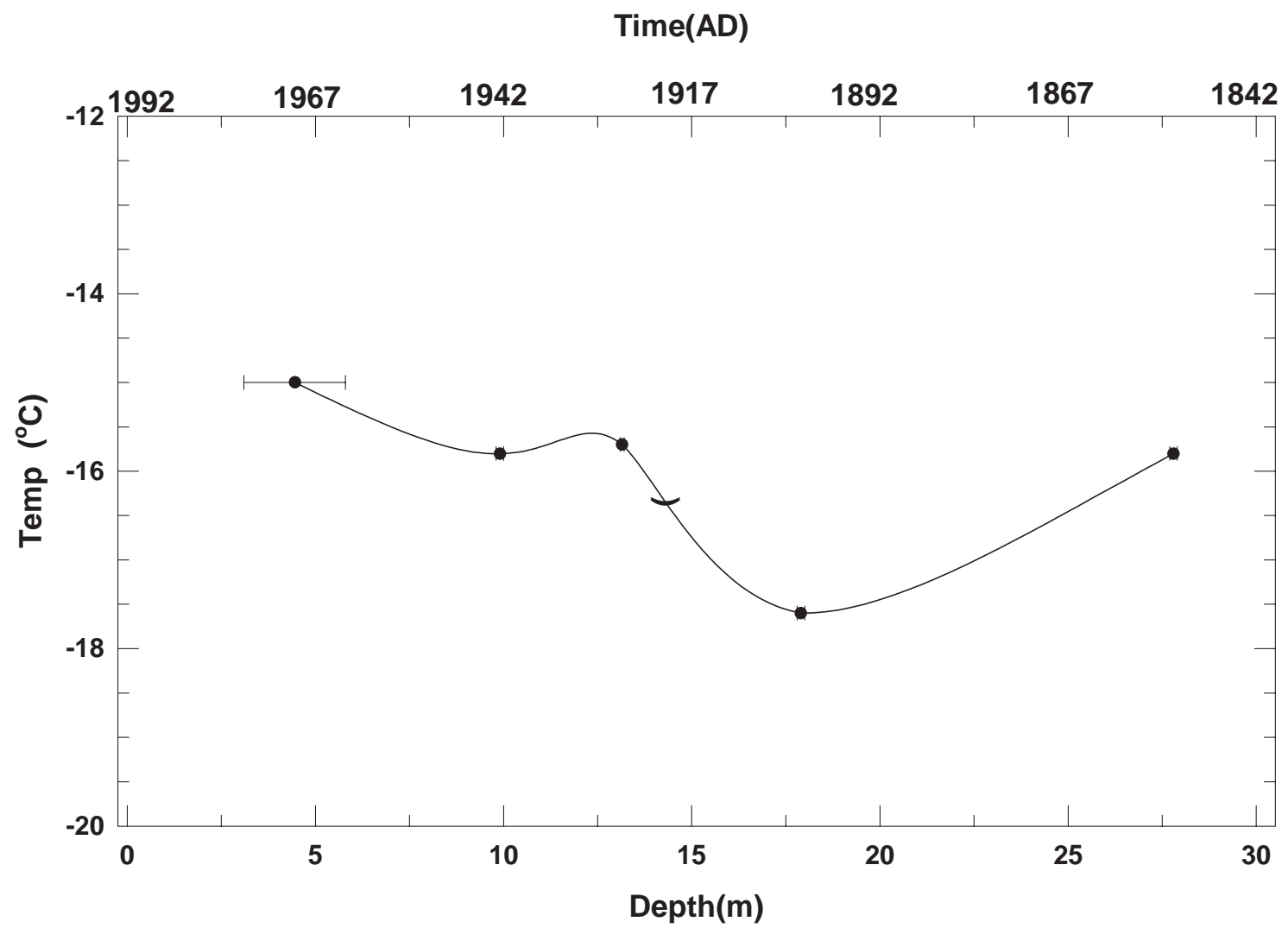

Figure 5. Average MASAT $\left({ }^{\circ} \mathrm{C}\right)$ values calculated during different time periods are plotted against depth (m) and time (AD). The lowest value is recorded around the beginning of the century and is cooler by $\sim 2^{\circ} \mathrm{C}$ than the recent past.

Table 3. Concentrations of ${ }^{10} \mathrm{Be}$ and ${ }^{36} \mathrm{Cl}$ in ice samples collected from $60 \mathrm{~m}$ ice core raised at Dakshin Gangotri from east Antarctica.

\begin{tabular}{|c|c|c|c|c|c|}
\hline \multirow{2}{*}{$\begin{array}{r}\text { Sl.No } \\
\\
1 .\end{array}$} & \multirow{2}{*}{$\begin{array}{c}\begin{array}{l}\text { Depth } \\
(\mathrm{cm})\end{array} \\
328\end{array}$} & \multirow{2}{*}{$\begin{array}{l}\begin{array}{l}\text { Volume } \\
(\mathrm{ml})\end{array} \\
630\end{array}$} & \multicolumn{2}{|c|}{$\begin{array}{l}\text { Concentration } \\
\left(\times 10^{4} \text { atoms } / \mathrm{g}\right) \\
10\end{array}$} & ${ }^{10} \mathrm{Be} /{ }^{36} \mathrm{C}$ \\
\hline & & & 1.38 & 0.219 & 6.30 \\
\hline 2. & 369 & 680 & 1.15 & 0.208 & 5.53 \\
\hline 3. & 410 & 1060 & 0.86 & 0.107 & 8.04 \\
\hline 4. & 447 & 920 & 1.13 & 0.207 & 5.46 \\
\hline 5. & 479 & 650 & 1.16 & - & - \\
\hline 6. & 508 & 680 & 2.58 & 0.200 & 12.90 \\
\hline 7. & 541 & 1000 & 0.82 & 0.151 & 5.43 \\
\hline 8. & 580 & 100 & 1.11 & 0.239 & 4.64 \\
\hline 9. & 620 & 1070 & 1.07 & 0.209 & 5.12 \\
\hline 10. & 660 & 1070 & 1.15 & 0.211 & 5.45 \\
\hline 11. & 694 & 570 & 0.79 & 0.154 & 5.13 \\
\hline 12. & 728 & 1145 & 1.26 & 0.235 & 5.36 \\
\hline 13. & 798 & 880 & 1.32 & 0.226 & 5.76 \\
\hline 14. & 833 & 1065 & 1.30 & 0.166 & 7.83 \\
\hline 15. & 968 & 900 & 0.85 & 0.245 & 3.47 \\
\hline 16. & 1026 & 1130 & 0.56 & 0.137 & 4.09 \\
\hline
\end{tabular}

Note: The errors on the ${ }^{10} \mathrm{Be}$ measurements are in the range of $6-9 \%$ whereas those for ${ }^{36} \mathrm{Cl}$ are within $25 \%$.

average in Antarctica than in Greenland (Raisbeck and Yiou 1985 and Steig et al 1996; Aldahan et al 1998). The ${ }^{10} \mathrm{Be}$ deposition flux calculated for Antarctic ice core by Aldahan et al (1998) and the estimates of ${ }^{10} \mathrm{Be}$ made by Lal et al 1987 are higher by a factor of 2 than that measured in the present work and that on Greenland ice core by a factor of 1.5 (Baumgartner et al 1997) probably due to the difference in the annual precipitation.

${ }^{36} \mathrm{Cl}$ measurements have been made for the time period (1980-40) which cover nuclear-weapon tests (see section 4.2 ). The ${ }^{36} \mathrm{Cl}$ values vary from 0.1 to $0.25 \times 10^{4}$ atoms $/ \mathrm{g}$ (table 3 ) with a mean value of $0.2 \times 10^{4}$ atoms $/ \mathrm{g}$. The mean deposition of ${ }^{36} \mathrm{Cl}$ has been estimated to be $3.91 \times 10^{4}$ atoms $/ \mathrm{cm}^{2}$ yr which agrees reasonably well with the global production rate of $4.09 \times 10^{4}$ atoms $/ \mathrm{cm}^{2}$ yr(i.e., $1.3 \times$ $10^{-3}$ atoms $/ \mathrm{cm}^{2} \mathrm{sec}$ ) by Lal and Peters (1967). The fallout of ${ }^{36} \mathrm{Cl}$ (based on a single measurement available prior to this work) in Antarctica is higher by a factor of $\sim 10$ (Finkel et al 1980) and that in Greenland for the cosmic ray component is higher by a factor of 2-6 compared to that in the present work.

Figure 6 shows variations in bi-annual (see section 3.2) concentrations of ${ }^{10} \mathrm{Be}$ and ${ }^{36} \mathrm{Cl}$ and their ratios $\left({ }^{10} \mathrm{Be} /{ }^{36} \mathrm{Cl}\right)$ and $\delta^{18} \mathrm{O}$ for the period 1980 1940 , a period of atmospheric nuclear tests. The ${ }^{36} \mathrm{Cl}$ concentrations unexpectedly do not show any variation throughout the period of bomb tests and the bomb pulse appears to be missing or diluted to cosmic ray background ${ }^{36} \mathrm{Cl}$ level at this loca- 

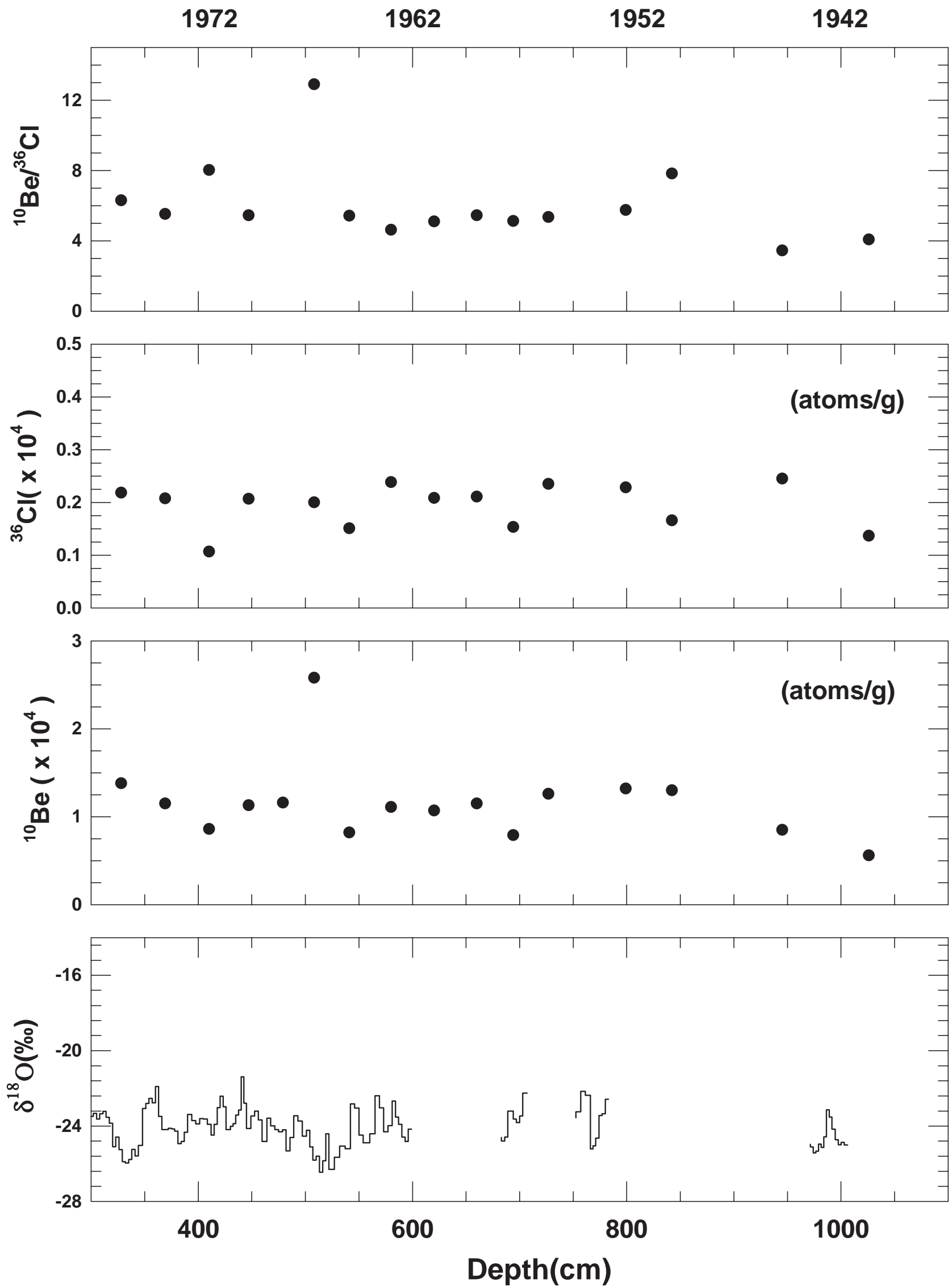

Figure 6. The concentrations of ${ }^{10} \mathrm{Be}$ and ${ }^{36} \mathrm{Cl}$ (atoms/g) and their ratios plotted against depth and time. The bomb pulse of ${ }^{36} \mathrm{Cl}$ could not be detected in the core section of 1940-1980 (see section 4.5 for discussion). These data are also plotted for $\delta^{18} \mathrm{O}$ which are good climatic indicators. 
tion. The cause for the "missing" ${ }^{36} \mathrm{Cl}$ is unclear, it probably could be due to its dilution during transport from the northen hemisphere to Antarctica. Earlier work in Greenland shows a bomb pulse of ${ }^{36} \mathrm{Cl}$ concentration during $1980-1940$, with concentrations by an order of magnitude higher than its cosmogenic contribution (Beer 1998, personnel communication; Synal et al 1990; Elmore et al 1982; Conard et al 1989). ${ }^{10} \mathrm{Be} /{ }^{36} \mathrm{Cl}$ ratios measured in the present work for the last $\sim 40$ years though show a wide range $3.5-13$, bulk of the samples have values $5 \pm 1$ (table 3 ) with one sample $>8$. The mean ${ }^{10} \mathrm{Be} /{ }^{36} \mathrm{Cl}$ in all samples is 7 which agrees well with that calculated to be 6.7 (Nishiizumi et al 1983) in surface ice from Yamato hills in Antarctica $\left(71^{\circ} 10^{\prime} \mathrm{S}, 35^{\circ} 07^{\prime} \mathrm{E}\right)$. We therefore suggest that the mean ${ }^{10} \mathrm{Be} /{ }^{36} \mathrm{Cl}$ ratio of 7 measured in the present work for the last $\sim 40$ years can be used as the initial ratio to date older ice from central Dronning Maud Land, east Antarctica (as indicated by Nishiizumi et al 1983 to date older ice from the Allan hills). The biannual data on ${ }^{10} \mathrm{Be}$ and ${ }^{36} \mathrm{Cl}$ for a short period in the present work are not sufficient to find out their correlations with solar activity, sunspot numbers and cosmic ray intensities etc. to draw meaningful conclusions.

The present limited data set does not give any explanation for the strange observation of the missing ${ }^{36} \mathrm{Cl}$ pulse at this location and more systematic measurements need to be carried out at the same or at neighbouring locations to justify the present observation.

\section{Conclusions}

- The mean accumulation rate of ice based on ${ }^{210} \mathrm{~Pb}(20 \pm 2 \mathrm{~cm} / \mathrm{yr}), \delta^{18} \mathrm{O}(21 \pm 0.02 \mathrm{~cm} / \mathrm{yr})$ and conductance $(17 \pm 0.05 \mathrm{~cm} / \mathrm{yr})$ has been estimated to be $\sim 19 \mathrm{~cm} / \mathrm{yr}$ in polar ice near the Indian station, east Antarctica for the past 150 years. The accumulation rate however shows significant interannual and decadal variations.

- The mean annual surface air temperature (MASAT) data observed during the last 150 years showed that the beginning of the 19th century was cooler by about $2^{\circ} \mathrm{C}$ than the recent past and middle of 18th century.

- It is intriguing that, unlike in Greenland, ${ }^{36} \mathrm{Cl}$ bomb pulse during the nuclear testing period (1980-1940 AD) is missing in the present location of East Antarctica.

- The mean ${ }^{10} \mathrm{Be} /{ }^{36} \mathrm{Cl}$ ratio of 7 for the last $\sim 40$ years may be used as the initial value to date older ice from east Antarctica.

\section{Acknowledgements}

We are grateful to Secretary, Department of Ocean Development, New Delhi for providing financial support and logistics for raising long ice core from east Antarctica. We are thankful to Dr P C Pandey, Advisor, Antarctic Study Center, Goa, India, for his encouragement and financial support towards the analysis of $\delta^{18} \mathrm{O}$ samples. We also thank $\mathrm{Mr}$ Astana of GSI, Antarctic division, India for his help in collecting the ice core samples. We also gratefully acknowledge the general manager, Vadilal Cold Storage, Ahmedabad, for his kind interest in promoting the scientific activities by allowing us to store the frozen ice core samples at $-20^{\circ} \mathrm{C}$ for a few years. We thank Dr Y B Acharya of PRL for extending his help in the assembling of indigenous conductance meter for measurement of electrical conductivity on solid ice core samples. We kindly acknowledge Prof. J Beer, P Kubik and $\mathrm{H}$ A Synal for their dedicated help in carrying out the ${ }^{10} \mathrm{Be}$ and ${ }^{36} \mathrm{Cl}$ measurements using AMS facility at ETH/AST in Zurich, Switzerland and useful discussions during the work. We also thank Profs. S Krishnaswami, N Bhandari and R Ramesh for fruitful discussions at various stages of the programme and help in improving the manuscript.

\section{References}

Aldahan A, Possnert G, Johnson S J, Clausen H B, lsaksson E, Karlen W and Hansson M 1998 Sixty year ${ }^{10}$ Be record from Greenland and Antarctica; Proc. Indian Acad. Sci (Earth Planet. Sci.) 107 139-147

Baumgartner S, Beer J, Suter M, Hannen B D, Synal H A, Kubik P W, Hammer C U and Johnsen S 1997 Chlorine 36 fallout in the summit Greenland ice core project ice core; J. Geophys. Res. 102 26659-26662

Beer J, Joos Ch F, Lukasczyk Ch, Mende W, Siegenthaler U and Stellmacher R $1994{ }^{10} \mathrm{Be}$ as an indicator of solar variability and climate; In: The solar engine and its influence on terrestrial atmosphere and climate (ed) Nesme-Ribes, E NATO ASI Series 25 221-233

Beer J, Raisbeck G M and Yiou F 1991 Time variations of ${ }^{10} \mathrm{Be}$ and solar activity; In: The sun in time (ed) $\mathrm{C}$ P Sonnett, M S Giampapa and M S Matthews (Tucson: University of Arizona Press), 343-359

Chaturvedi A and Asthana R 1996 An attempt at shallow ice-core drilling in polar continental ice, central Dronning Maud Land; 12th Indian Expedition to Antarctica DOD Tech. Publ. No. 10 77-99

Conard N J, Kubik P W, Gove H E and David Elmore $1989 \mathrm{~A}^{36} \mathrm{CI}$ profile in Greenland ice from 1265 to 1865 ; Radiocarbon 31 585-591

Crozaz G, Picciotto E and W De Breuk 1964 Antarctic snow chronology with ${ }^{210} \mathrm{~Pb}$; J. Geophys. Res. $692597-2604$

Crozaz G and C C Langway Jr 1966 Dating Greenland firnice cores with Pb-210; Earth Planet. Sci. Lett. 1 194-196

Currie R 1994 Variance contribution to Iuni-solar and solar cycle signals in the St. Lawrence and Nile river records; Internat. J. Climatology 14 843-852

Dansgaard W 1964 Stable isotopes in precipitation; Tellus $16436-468$ 
Delmas R J, Krichner S, Palis J M and Petit J R 19921000 years of explosive volcanism records at the south pole; Tellus 44B 335-350

Elmore D, Tubbs L E, Newman D, Ma X Z, Finkel R, Nishiizumi K, Beer J, Oeschger H and M Andree $1982{ }^{36} \mathrm{CI}$ bomb pulse measured in a shallow ice core from Dye 3 , Greenland; Nature 300 735-737

Finkel R C, Nishiizumi K, Elmore D, Ferraro R D and Gove $\mathrm{H}$ E $1980{ }^{36} \mathrm{CI}$ in polar ice, rain water and sea water; Geophys. Res. Lett. 7 983-986

Gaggeler H, Von Gunten H R, Rossler E, Oeschger H and Schotterer U $1983{ }^{210} \mathrm{~Pb}$ dating of cold alpine firn/ice cores from Colle Gnifetti, Switzerland; J. Glaciology 101 $165-177$

Hammer C U 1980 Acidity of polar ice cores in relation to absolute dating, past volcanism and radio-echos; $J$. Glaciology 93 359-372

Hammer C U, Clausen H B and Langway Jr C C 1997 50,000 years of recorded global volcanism; Climate Change $\mathbf{3 5}$ $1-15$

Jouzel J and 6 others 1987 Vostok ice core: a continuous isotope temperature record over the last climatic cycle (160,000 yrs); Nature 329 1-6

Lal D and Peters B 1976 Cosmic ray produced radioactivity on the Earth: In: Handbuch der Physik, 46 (Berlin, Springer-Verlag) 551-612

Lal D $1987{ }^{10} \mathrm{Be}$ in polar ice : data reflect changes in cosmic ray flux or polar meteorology; Geophys. Res. Lett. 14 $785-788$

Nijampurkar V N and Rao D K 1993a Ice dynamics and climatic studies on Himalayan glaciers based on stable and radioactive isotopes, Snow and Glacier Hydrology, IAHS publication 218 355-369

Nijampurkar V N and Rao D K 1993b Polar fallout of radionuclides ${ }^{32} \mathrm{Si},{ }^{7} \mathrm{Be}$ and ${ }^{210} \mathrm{~Pb}$ and past accumulation rate of ice at Indian station Dakshin Gangotri, east Antarctica; J. Environ. Radioactivity 21 $107-117$
Nishiizumi K, Arnold J R, Elmore D, Ma K, Newman D and Gove H E $1983{ }^{36} \mathrm{CI}$ and ${ }^{53} \mathrm{Mn}$ in Antarctic meteorites and ${ }^{10} \mathrm{Be}-{ }^{36} \mathrm{CI}$ dating of Antarctic ice; Earth. Planet. Sci. Lett. $62407-417$

Orheim O, Gjessing Y, Lunde T, Repp K, Wold B, Clausen H B and Liestol O 1986. Oxygen isotopes and accumulation rates at Riiser-Larsenisen, Antarctica; Nor. Polarinst. Skr. $18733-37$

Petterson G, Renberg I, Geladi P, Lindberg A and Lindgren F 1993 Spatial uniformity of sediment accumulation in varved lake sediments in Northern Sweden, J. Palaeolimnology 9 195-208

Picciotto E, Crozaz G and W De Breuk 1964 Rate of accumulation of snow at the south pole as determined by radioactive measurements; Nature, 203 393-394

Raisbeck G M and F Yiou $1985{ }^{10} \mathrm{Be}$ in polar ice and atmospheres; Annals of Glaciology 7 138-140

Ramesh R, Bhattacharya S K and Pant G B 1989 Climatic significance of $\delta \mathrm{D}$ variations in tropical tree species from India; Nature 337 149-150

Sarin M M, Ravi Bhushan, Rengarajan R and Yadav D N 1992 Simultaneous determination of ${ }^{238} \mathrm{U}$ series nuclides in water of Arabian Sea and Bay of Bengal; Indian Journal of Marine Sciences 21 121-127

Seleshi Y, Demaree G R and Delleur J W 1994 Sunspot numbers as a possible indicator of annual rainfall at Addis Ababa, Ethiopia; Internat. J. Climatology 14 911-923

Steig E J, Polissar P J, Stuiver M, Grootes P M and Finkel R C 1996 Large amplitude solar modulation cycles of ${ }^{10} \mathrm{Be}$ in Antarctica: implication for atmospheric mixing processes and interpretation of the ice core record ; Geophys. Res. Lett. 23 523-526

Stuiver M, Grootes P M and Braziunas T F 1995 The GISP2 $\delta^{18} \mathrm{O}$ climate record of the past 16,500 years and the role of sun, ocean and volcanoes; Quat. Res. 44 341-354

Synal H A, Beer J, Bonani G, Sute M and Wolfli W 1990 Atmospheric transport of bomb produced ${ }^{36} \mathrm{Cl} ; \mathrm{Nucl}$ Instr. Meth B52 483-488 